\title{
A baseline climatology of sounding-derived parameters associated with heavy rainfall over Gauteng, South Africa
}

LiesI L Dyson, Johan van Heerden and Paul D Sumner

Department of Geography Geoinformatics and Meteorology, University of Pretoria, Pretoria, South Africa

Corresponding author

Liesl Dyson

liesl.dyson@up.ac.za

University of Pretoria

Private bag X20

Hatfield 0028

South Africa

Tel: $+\mathbf{2 7 1 2 4 2 0 2 4 6 9}$ 


\begin{abstract}
Irene weather office sounding data are considered a proximity sounding for the Gauteng province of South Africa. Sounding-derived parameters are analysed for 35 austral summers from 1977 to 2012. The goal of this study is to provide a climatology of sounding-derived parameters commonly used as ingredients to forecast heavy rainfall. The emphasis is placed on identifying those variables that distinguish between climatology and heavy rainfall events. Special attention is given to how the critical values associated with heavy rainfall change from early to late summer.
\end{abstract}

During early summer (October to December), the atmospheric circulation over Gauteng is markedly extra-tropical in nature. Heavy rainfall occurs in a conditionally unstable atmosphere and is associated with conditions conducive to the development of severe storms, such as large wind shear and convective available potential energy (CAPE) values, strong upper tropospheric winds and large temperature lapse rates. In late summer (January to March), the atmosphere takes on distinct tropical characteristics and becomes increasingly convectively unstable. During this time of year there is abundant moisture in circulation and the storms that develop are highly efficient in producing precipitation. Forecasting heavy rainfall in early summer requires different techniques than in late summer.

Sounding parameters, which provide information about the moisture content of the atmosphere, are capable of distinguishing between climatology and heavy rainfall during all summer months. The only other variables capable of doing this are the average meridionial wind direction in the 800 to $600 \mathrm{hPa}$ layer, the mean layer equivalent potential temperature, the Showalter Index (SI), the K-Index (KI) and the Elevated K-Index (EKI). However, critical values associated with heavy rainfall for all these parameters change month by month.

Key words: Gauteng, heavy rainfall, climatology, sounding, atmospheric instability, convection, South Africa. 


\section{Introduction}

South Africa is a semi-arid country with an average annual rainfall of about $450 \mathrm{~mm}$. Over the north-western interior, bordering Namibia, and the northern parts of the west coast, the annual rainfall can be as low as $25 \mathrm{~mm}$, but the rainfall amounts generally increase towards the south and east. More than $500 \mathrm{~mm}$ occurs over the eastern half of the country (Taljaard, 1996b) and there are only a few isolated areas along the east coast and the Drakensberg Mountains, as well as the elevated areas in the Western Cape, that receive more than 1000 $\mathrm{mm}$ of rain per annum. These regions are identified in the insert of Fig. 1. However, heavy rainfall and flooding is not uncommon in South Africa and is often associated with large financial losses, damage to infrastructure and loss of life. The South African Weather Bureau (SAWB, 1991) lists 184 noteworthy flood events that occurred over South Africa during the period 1911-1988. Close to 30\% of these flood events occurred over KwaZulu-Natal and 42\% occurred over the four northern provinces (Limpopo, North-West, Gauteng and Mpumalanga) and the central interior of South Africa (Alexander and Van Heerden, 1991). Furthermore, between 1990 and 2012, several remarkable flood events occurred over South Africa. A few examples include the floods in February 1996 over the central interior (De Coning et al., 1998) and the widespread heavy rainfall over the northern provinces of South Africa in February 2000 (Dyson and Van Heerden, 2001). During the summer rainfall seasons (October to March) of $2009 / 10$ and $2010 / 11$, above normal rainfall occurred over much of the summer rainfall area (Department of Water Affairs (DWA), 2012). The summer of 2009/10 was particularly wet as floods occurred in seven of the nine provinces of South Africa (Dyson, 2013).

The focus of this research is on heavy rainfall during the austral summer (October to March) over the Gauteng province of South Africa which receives summer rainfall. Gijben (2012) showed that rainfall in summer over the interior of South Africa is essentially convective in 


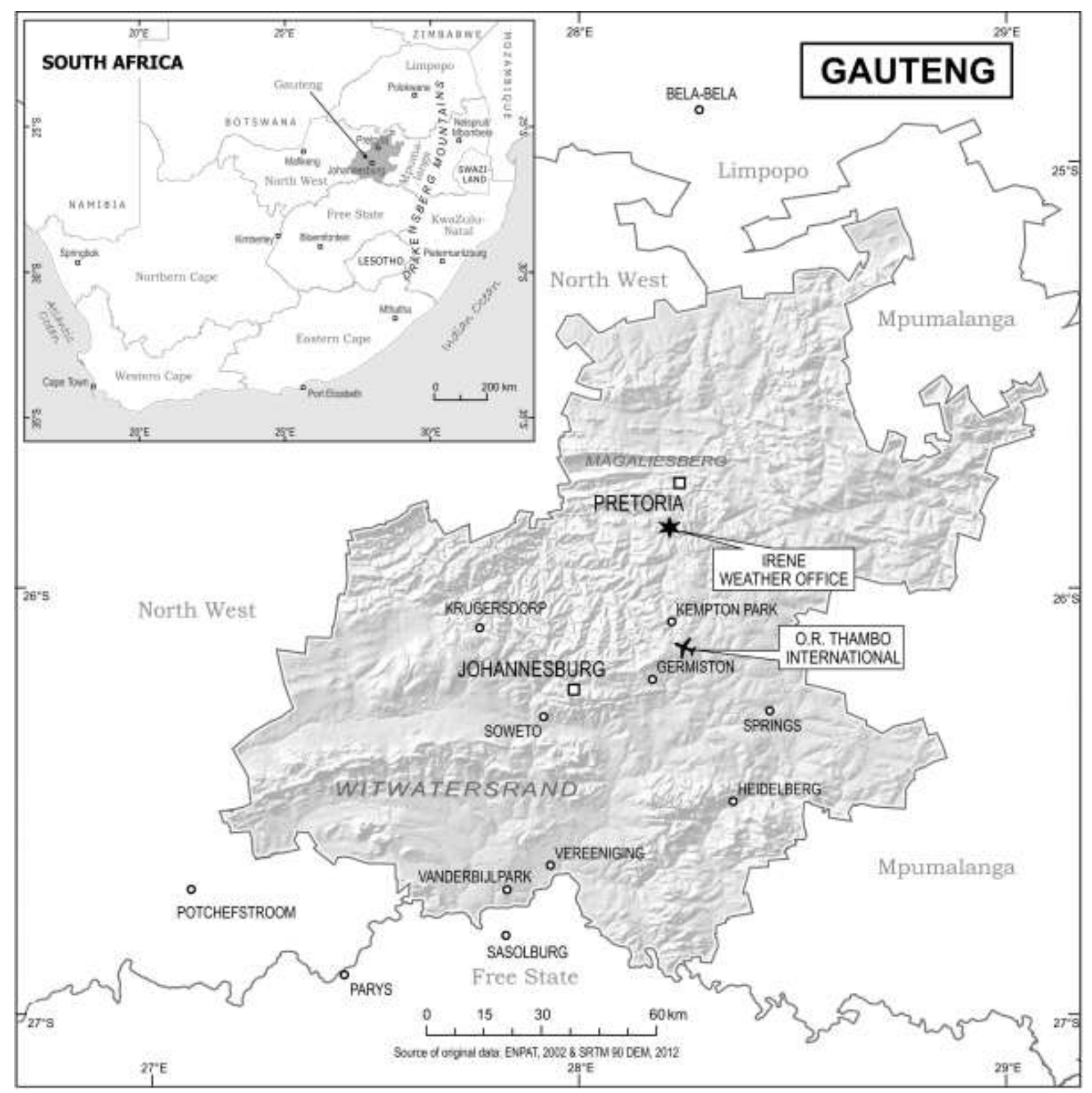

Figure 1: Location map of Southern Africa and the Gauteng Province. 
nature. He states that most of the summer rainfall area of South Africa receives on average between five and ten lightning ground strokes per square kilometre per year. Over the escarpment of Mpumalanga, there are 20 to 50 lightning strokes per annum in a square kilometre, while the Witwatersrand, in the southern part of Gauteng, receives 10 to 15 ground strokes per square kilometre per year Gijben (2012). It is therefore important to note that, irrespective of the type of weather system responsible for rainfall over the summer rainfall area, convection, together with the accompanying atmospheric instability, plays an important role in its development.

This paper describes the thermodynic characteristics of the atmosphere, as portrayed by sounding derived parameters, during heavy rainfall in summer over Gauteng. Emphasis is placed on indicating how the character of the atmosphere changes from one with extratropical characteristics in early summer to distinctly tropical as the summer progress. The thermodynamic state of the atmosphere is a function of several factors and in particular the synoptic circulation patterns. Exhaustive literature exists linking synoptic scale weather systems to heavy rainfall over South Africa and Gauteng. This paper does not attempt to identify or classify the synoptic scale circulation causing heavy rainfall over Gauteng but describes how the character of the atmosphere changes during summer. In early summer Cutoff Lows (COLs) and other westerly troughs such as the tropical temperature trough (TTTs) and ridging surface high pressure systems have been associated with heavy rainfall over Gauteng (Taljaard, 1985; Taljaard ,1996b; Tyson and Preston-White ,2000; Singleton and Reason, 2007; Hart et al., 2010). In late summer weather systems such as V-shaped troughs, continental tropical weather systems and tropical cyclones may cause heavy rainfall over the northeastern interior of South Africa (Taljaard, 1996b; . De Coning et al., 1998; Dyson and van Heerden, 2002; Malherbe et al., 2012) The TTT in late summer may be responsible for 
advecting large amounts of moisture from the ITCZ to the southern Africa plateau (Hart et al., $2010)$

Rasmussen and Blanchard (1998) explain how weather forecasters often rely on subjective experience when identifying favourable parameters for thunderstorm forecasting. Parameters such as convective available potential energy (CAPE) or the $K$-Index are in general use in an operational environment and are often used to research heavy rainfall or severe storms. These parameters and their threshold values are used in case studies and forecasting, but not necessarily with thorough climatological verification. A baseline climatology provides objective information on favourable parameters and what values constitute climatologically large or extreme values. In recent years, many studies have been undertaken where sounding-derived parameters are associated with severe weather phenomena. Examples are Manzato (2003), Craven and Brooks (2004), Doswell and Schultz (2006), Dupilka and Reuter (2006a and 2006b), Groenemeijer and Van Delden (2007), Covadonga et al. (2010) and Dimitrova et al. (2009). Most, if not all, of these studies have been undertaken in the USA or Europe. In each instance, a set of ingredients was identified that may be associated with severe weather for a specific geographical location.

The southern subcontinent of Africa is characterised by a moderately elevated plateau, for the greater part rising to over $1000 \mathrm{~m}$ above sea level and to more than $1500 \mathrm{~m}$ over extensive areas (Taljaard, 1994). Height above sea level and the complexity of the terrain has a significant influence on circulation and the thermodynamic parameters. For example, Bunkers et al. (2010) state that using the $700 \mathrm{hPa}$ temperature as a proxy for the capping inversion is useful over the USA, but not in elevated terrain. Bosart et al. (2006) propose that significant tornadoes over mountainous terrain require a deeper mesocyclone than at lower elevations. They also state that convective available potential energy (CAPE) values are higher over the 
plains than over elevated terrain. Daniel (2006) proposes specific techniques to forecast the mixed-layer height over mountains. The elevated plateau ( $\pm 1500 \mathrm{~m}$ above mean sea level) over the interior of South Africa likewise has a significant influence on the thermodynamic profile and moisture content of the atmosphere. Threshold values and ingredients identified over other parts of the globe are therefore not necessarily directly applicable to Gauteng. Upper air soundings are done regularly at about 5 locations in southern Africa and only two of these places are over the interior (Irene and Bloemfontein). Soundings over the elevated plateau in subtropical southern Africa are therefore very rare and this paper contributes to understanding atmospheric processes and thermodynamics over an elevated terrain in a data scarce area.

The purpose of this study is to provide a climatology of sounding-derived parameters commonly used as ingredients to forecast heavy rainfall over the Gauteng province of South Africa (Fig. 1). A comprehensive climatology is developed of environmental conditions that occur in conjunction with heavy summer rain in Gauteng. Information is provided of typical values of these parameters during heavy rainfall events and those variables are identified that have significantly different values when heavy rainfall occurs in comparison to the climatological values. Information is also provided on the seasonal variability of these parameters as the atmospheric circulation over the interior plateau of southern Africa changes from extra-tropical in early summer to tropical in late summer (Dyson, 2013). This research follows the approach of Harnack et al. (1998), who determined whether the sounding data can be used to discriminate between conditions occurring on a day with heavy rain and those of a climatological mean in Utah in the USA. No such investigation has yet been undertaken in South Africa and this research provides the ingredients associated with heavy rainfall over Gauteng. This study is conducted over a 35-year period for summer months and serves as an 
instrument to investigate the seasonal variability of the thermodynamic profile of the atmosphere during heavy rainfall over an elevated area.

\section{Study area}

This paper focuses on the Gauteng province (hereafter Gauteng) in South Africa (Fig. 1). Gauteng falls in the summer rainfall area of South Africa and is situated over the northeastern part of the country. Although Gauteng is an area defined by political boundaries, there are several meteorological factors for choosing this study area. Gauteng is situated over the interior plateau of South Africa, with an average height of $1500 \mathrm{~m}$ above mean sea level (AMSL). The Witwatersrand in the south of Gauteng is between 1700 and $1800 \mathrm{~m}$ AMSL. The elevation gradually decreases towards the north and Irene is situated at $1500 \mathrm{~m} \mathrm{AMSL}$ and Pretoria at $1330 \mathrm{~m}$ AMSL. North of Pretoria the Magaliesberg rises to between $1600-1700 \mathrm{~m}$ AMSL. The elevated areas of the Witwatersrand in the south receive $700 \mathrm{~mm}$ of rain per annum, with $600 \mathrm{~mm}$ north of the Magaliesberg. Gauteng is cool with an average annual maximum temperature of $22{ }^{\circ} \mathrm{C}$ in the south and $25^{\circ} \mathrm{C}$ in the north. Taljaard (1996a) indicated that height above sea level is one of the main factors determining the surface temperature distribution over the interior plateau of South Africa. In January months over Gauteng the average temperature is close to $4{ }^{\circ} \mathrm{C}$ lower than at sea level at corresponding latitudes. There are about 100 days with rain in Johannesburg (south) and 85 in Pretoria (north) (Kruger, 2004). The entire province receives predominantly summer rainfall from weather systems that are conducive to convective development (Gijben, 2012). Even though there is some variation in rainfall, topography and temperature over Gauteng, the area has similar climatological characteristics. Ample meteorological data are available in the province. There are two main weather offices in Gauteng, at OR Tambo International Airport and the head office of the 
South African Weather Service (SAWS) in Pretoria (Fig. 1). Upper air soundings are done daily at the Irene weather office, located in the centre of the province, and there are about 50 rainfall stations in Gauteng (Dyson, 2009).

Gauteng is the smallest of South Africa's nine provinces, but has the largest number of population. It is responsible for over a third of South Africa's gross domestic product (GDP) and a tenth of Africa's GDP according to Statistics South Africa (StatsSA, 2013). Gauteng is therefore a very important contributor to the economy of South Africa and the disruption of infrastructure due to heavy rainfall and floods could result in large financial losses. There are also several vulnerable communities who live in temporary shacks on vacated land close to rivers (Beavon, 2004). Early warning of heavy rainfall could mitigate the impact that floods and flash floods have on these communities.

\section{Sounding-derived parameters}

Much work has been done that relates sounding-derived parameters to severe storms and heavy rainfall. Table 1 provides a summary of the parameters that are used in this paper. These parameters were chosen as they either capture the change in characteristics of the atmosphere from early to late summer or they have been shown to be in some way or other an ingredient of heavy rainfall and severe thunderstorms.

A complete discussion of the rationale, including all the different parameters listed in Table 1, is not provided here, but a comprehensive list of the authors who have defined and used the parameters is tabulated. Selected variables are discussed in more detail below in the context of the results found. 
Table 1: Equations, units and abbreviations of sounding parameters. The following symbols are used: (T) Temperature $\left({ }^{\circ} \mathrm{C}\right),(\mathrm{Z})$ Geopotential height $(\mathrm{gpm})$, (q) Mixing ratio $\left(\mathrm{kg} \mathrm{kg}^{-1}\right)$, (p) Pressure (Pa in all calculation), (v) Meridionial wind speed $\left(\mathrm{ms}^{-1}\right)$, (u) Zonal wind speed $\left(\mathrm{ms}^{-1}\right)$.

\begin{tabular}{|c|c|c|c|c|}
\hline Parameter & Units & Abbreviation & Equation & Authors \\
\hline $\begin{array}{l}\text { Mean temperature in a } \\
\text { layer }\end{array}$ & ${ }^{\circ} \mathrm{C}$ & $\mathrm{T}_{\mathrm{p} 1, \mathrm{p} 2}$ & $\begin{array}{l}\text { Average temperature between } \mathrm{p} 1 \text { and } \\
\text { p2 }\end{array}$ & Dyson and van Heerden (2001) \\
\hline $\begin{array}{l}\text { Temperature } \\
\text { difference in the } \\
\text { vertical }\end{array}$ & ${ }^{\circ} \mathrm{C}$ & $\mathrm{TD}_{\mathrm{p} 2, \mathrm{p} 1}$ & where $\mathrm{p} 2>\mathrm{p} 1$ & $\begin{array}{l}\text { Doswell et al. (1985), Craven and Brooks } \\
\text { (2004) }\end{array}$ \\
\hline $\begin{array}{l}\text { Dew point } \\
\text { temperature at } \\
500 \mathrm{hPa}\end{array}$ & ${ }^{\circ} \mathrm{C}$ & $\mathrm{Td}_{500}$ & & Harnack et al. (1998) \\
\hline $\begin{array}{l}\text { Mean layer dew point } \\
\text { temperature }\end{array}$ & ${ }^{\circ} \mathrm{C}$ & $\mathrm{Td}_{100}$ & $\begin{array}{l}\text { Average dew point temperature in the } \\
100 \mathrm{hPa} \text { above ground level }\end{array}$ & $\begin{array}{l}\text { Craven et al. (2002), Craven and Brooks } \\
\text { (2004) }\end{array}$ \\
\hline Precipitable water & $\mathrm{mm}$ & PW & $P W=\frac{1}{g} \sum_{i=850 h P a}^{i=300 h P a} \frac{q\left(p_{i}\right)+q\left(p_{i+1}\right)}{2} \quad\left(p_{i}-p_{i+1}\right)$ & $\begin{array}{l}\text { Harnack et al. (1998), Dupilka and Reuter } \\
\text { (2006b) }\end{array}$ \\
\hline $\begin{array}{l}\text { Mean wind speed at a } \\
\text { pressure level }\end{array}$ & $\mathrm{ms}^{-1}$ & $W_{p}$ & & Ramaswamy (1956), Doswell et al. (1996) \\
\hline Bulk wind shear & $\mathrm{ms}^{-1}$ & $\mathrm{BS}_{\mathrm{p} 1, \mathrm{p} 2}$ & Magnitude of vector difference & $\begin{array}{l}\text { Doswell et al. (1996), Craven and Brooks } \\
\text { (2004), Brimelow et al. (2002), Dupilka and } \\
\text { Reuter (2006a), Cohen et al. (2007) }\end{array}$ \\
\hline $\begin{array}{l}\text { Mean meridionial } \\
\text { wind speed in a layer }\end{array}$ & $\mathrm{ms}^{-1}$ & $V_{p 1, p 2}$ & $\begin{array}{l}\text { Average meridionial wind speed of all } \\
\text { pressure levels between } \mathrm{p} 1 \text { and } \mathrm{p} 2\end{array}$ & \\
\hline $\begin{array}{l}\text { Mean layer equivalent } \\
\text { potential temperature }\end{array}$ & K & $\Theta_{\mathrm{e} 100}$ & $\begin{array}{l}\text { Average } \Theta_{\mathrm{e}} \text { in the } 100 \mathrm{hPa} \text { above ground } \\
\text { level }\end{array}$ & $\begin{array}{l}\text { Omotosho et al. (2000), Berry and } \\
\text { Thorncroft (2005), Houston and } \\
\text { Wilhelmson (2012) }\end{array}$ \\
\hline $\begin{array}{l}\text { Equivalent potential } \\
\text { temperature lapse rate }\end{array}$ & K & $\Delta \theta_{\mathrm{ep2}, \mathrm{p} 1}$ & where $\mathrm{p} 2>\mathrm{p} 1$ & Schultz et al. (2000), Cohen et al. (2007) \\
\hline $\begin{array}{l}\text { Mean layer convective } \\
\text { available potential } \\
\text { energy }\end{array}$ & $\mathrm{J} \mathrm{kg}^{-1}$ & CAPE & $\begin{array}{l}\text { CAPE calculated with the average dew } \\
\text { point temperature in the lowest } 50 \mathrm{hPa} \\
\text { above the surface }\end{array}$ & $\begin{array}{l}\text { Williams and Renno (1993), Doswell and } \\
\text { Rasmussen (1994), Brimelow et al. (2002), } \\
\text { De Rubertis (2006), Dupilka and Reuter } \\
\text { (2006a), Chaudhari et al. (2010), Tyagi et } \\
\text { al. (2011) }\end{array}$ \\
\hline Showalter index & ${ }^{\circ} \mathrm{C}$ & $\mathrm{SI}$ & $\begin{array}{l}\text { Parcel temperature lifted from } 850 \mathrm{hPa} \\
\text { (calculated using mean mixing ratio in } \\
\text { lowest } 100 \mathrm{hPa} \text { ) }- \text { environmental } \\
\text { temperature at } 500 \mathrm{hPa}\end{array}$ & Costa et al. (2001), De Rubertis (2006) \\
\hline$K-$ Index & ${ }^{\circ} \mathrm{C}$ & $\mathrm{KI}$ & $\mathrm{T}_{850}-\mathrm{T}_{500}+\mathrm{Td}_{850}-\left(\mathrm{T}_{700}-\mathrm{Td}_{700}\right)$ & Henry (2000), De Rubertis (2006) \\
\hline Elevated $K$-Index & ${ }^{\circ} \mathrm{C}$ & EKI & $\mathrm{T}_{700}-\mathrm{T}_{500}+\mathrm{Td}_{700}-\left(\mathrm{T}_{600}-\mathrm{Td}_{600}\right)$ & Todd (2010) \\
\hline Warm cloud depth & $\mathrm{hPa}$ & WCD & $\begin{array}{l}\text { Pressure of freezing level - pressure of } \\
\text { local condensation level (LCL) }\end{array}$ & $\begin{array}{l}\text { Market et al. (2003), Schumacher and } \\
\text { Johnson (2008) }\end{array}$ \\
\hline
\end{tabular}




\section{Data and methodology}

Upper air data from the Irene weather office are used to calculate the sounding parameters. Brooks et al. (1994) provide a detailed discussion of the difficulties in defining a proximity sounding. The challenge is to sample the atmosphere in which the event formed. The main concerns are that the atmosphere is not spatially homogeneous and changes with time. Darkow (1969), cited in Brooks et al. (1994), considered a proximity sounding when the sounding was done within $80 \mathrm{~km}$ of an event (tornadoes in his investigation), but Rasmussen and Blanchard (1998) preferred $400 \mathrm{~km}$. Craven and Brooks (2004) considered a distance of $185 \mathrm{~km}$ between the event and the sounding location to be a proximity sounding, while Groenemeijer and Van Delden (2007) chose a maximum distance of $100 \mathrm{~km}$ in order to retain a reasonable number of soundings for different types of severe weather events. Potvin et al. (2010) compared different proximity criteria (spatial and temporal) to understand the sensitivity of sounding-derived parameters to the proximity criteria. They found that a sounding collected 40 to $80 \mathrm{~km}$ from a tornado was most representative of the storm environment. Soundings that were done closer to the tornado tended to be less representative due to the convective feedback processes, and sounding collected further than $80 \mathrm{~km}$ from the tornado was more representative of the larger-scale environment. Potvin et al. (2010) also concluded that on the temporal scale, soundings done within zero to two hours of the tornado were most representative. Darkow (1969) suggested that unrepresentative soundings should be eliminated, but Brooks et al. (1994) explained some of the pitfalls in this approach. Placing strict constraints on the spatial and temporal variability of the atmosphere may eliminate a large number of soundings, limiting the statistical significance of the results obtained from the remaining soundings. 
The Irene sounding is considered in this research to be a proximity sounding for Gauteng, as the boundaries of the province are within $100 \mathrm{~km}$ of Irene. Irene is located in the center of Gauteng with no major topographical obstacles in its vicinity. The Magaliesburg lies $50 \mathrm{~km}$ to the north and the topography rises gently to the Witwatesrand in south. The rainfall data used to calculate daily rainfall were only available in 24 -hour periods for the entire 35 summers under investigation. Therefore, the time of the event is not considered, but a generalisation is made that the 1200 UTC soundings are most representative of the atmospheric conditions prior to the onset of rainfall. Rainfall over the summer rainfall area in South Africa occurs most frequently just after 1800 UTC (Rouault et al., 2013). The 1200 UTC sounding would therefore generally be done prior to the onset of rainfall. Dyson et al. (2012) indicate that heavy rainfall over Gauteng is associated with an above normal number of lightning strikes and heavy rainfall is thus predominantly convective in nature. Considering the convective nature of rainfall over Gauteng, where surface temperatures play an important role, and in an attempt to sample the atmosphere prior to the occurrence of heavy rainfall, it was decided to use the 1200 UTC soundings as a proxy in the investigation into heavy rainfall. The convective temperature is the surface temperature in the sounding dataset.

The South African Weather Service (SAWS) Irene upper air data were acquired from http://www.weather.uwyo.edu/ for the 35 austral summers from October 1977 to March 2012. The raw data include pressure, temperature, geopotential height, dew point depression, wind direction and wind speed on standard and significant pressure levels. There is no evidence for consistent quality control of these data over the entire period and quality control procedures were therefore implemented. It is important to have confidence in the quality of the data used to calculate the parameters. As this research develops a 35-year climatology of the sounding parameters, it is possible, following the logic of Craven and Brooks (2004), that erroneous or contaminated data will be masked by the statistical analysis. However, very 
heavy rainfall events are rare over Gauteng (Dyson, 2009), and bad data may not be masked efficiently due to the small number of these events. A further challenge in interpreting any data, as Brooks and Stensrud (2000) explain, is that rare interesting events and bad data often look similar. Quality control processes similar to those described by the Global Radiosonde Archive (Durre et al., 2006) were implemented on the Irene sounding data. These checks were only preformed at pressures higher than $300 \mathrm{hPa}$. Table 2 lists the quality control procedures employed and also provides information on the action taken for each of the checks. In addition, a third set of errors (not indicated in Table 2) was also identified. This is referred to as the climatological checks. Here long-term average values of temperature, dewpoint temperature and wind strength were calculated at $50 \mathrm{hPa}$ pressure intervals. The data in each sounding were compared to the climatological mean values and was rejected if it differed by more than six standard deviation points from the average. However, this was only done after visual inspection of these soundings.

In this research, daily heavy rainfall is defined as when at least one station over Gauteng receives at least $50 \mathrm{~mm}$ of rain in 24 hours. Dyson (2009) explains that this $50 \mathrm{~mm}$ threshold is close to the $90^{\text {th }}$ percentile of daily 24-hour summer rainfall over Gauteng. The sounding data are used to discriminate atmospheric conditions associated with heavy rainfall (HEAVY) from the climatological mean (CLIM). The number of HEAVY soundings is approximately $5 \%$ of the CLIM soundings.

The unequal variance $t$-test or Welch's $t$ test is employed to test the null hypothesis that the mean of the CLIM sample is equal to the mean of the HEAVY sample and is rejected at a confidence level of $10 \%$. 
Table 2: Quality control procedures in the Irene sounding data (after Durre et al., 2006).

\begin{tabular}{|c|c|}
\hline Type of check and items deleted & Quality control test \\
\hline $\begin{array}{l}\text { Data completeness check - remove } \\
\text { soundings }\end{array}$ & $\begin{array}{l}\text { - } \quad<10 \text { pressure levels between surface and } 300 \mathrm{hPa} \\
\text { - } \mathrm{T} \text { and } \mathrm{Td} \text { not available from surface to } 300 \mathrm{hPa} \\
\text { - } \quad 200 \mathrm{hPa} \text { pressure difference between two sequential } \\
\text { - } \text { pressure levels } \\
\text { - } \text { Surface pressure does not decrease with height } \\
\text { - } \mathrm{T} \text { at surface }<-10{ }^{\circ} \mathrm{C} \\
\text { - } \mathrm{hPa} \\
\text { - } \text { Tlapse rate in the mid-levels }>\text { dry adiabatic lapse rate } \\
\text { - }\end{array}$ \\
\hline $\begin{array}{l}\text { Fundamental sanity check - remove } \\
\text { individual elements }\end{array}$ & $\begin{array}{ll}\text { - } & -120^{\circ} \mathrm{C}>\mathrm{T}>45^{\circ} \mathrm{C} \\
\text { - } & \mathrm{T}<-65^{\circ} \mathrm{C} \text { when } \mathrm{P}>300 \mathrm{hPa} \\
\text { - } & \text { Wind speed }>200 \mathrm{kt} \\
\text { - } & 0>\text { wind direction }>360^{\circ} \\
\text { - } & \mathrm{rh}>100 \% \\
\text { - } & 70{ }^{\circ} \mathrm{C}<\mathrm{T}-\mathrm{Td}<0{ }^{\circ} \mathrm{C} \\
\text { - } & \mathrm{T}>0{ }^{\circ} \mathrm{C}, \text { when } \mathrm{P}<500 \mathrm{hPa} \\
\text { - } & \mathrm{T} \text { and } \mathrm{Td} \text { spike checks }\end{array}$ \\
\hline
\end{tabular}


One of the limitations of this research is the proximity criteria and, specifically, the assumption that the 1200 UTC sounding is representative of the heavy rainfall event. The results obtained must be seen to represent the larger-scale environment in which the heavy rainfall occurs.

\section{Results}

\subsection{Synoptic circulation}

The National Centre for Environmental Prediction (NCEP) reanalysis data (Kalnay, et al., 1996) were used to create composite maps of atmospheric flow fields for days on which heavy rainfall occurred (Fig. 2a and Fig. 2b). Maps are only shown for October and February, as these months are representative of the two different circulation regimes that exist in summer over South Africa.

For HEAVY October months, the surface ( $850 \mathrm{hPa}$ ) trough lies over the western interior with the Indian Ocean High $(\mathrm{IOH})$ over the eastern extremes of the subcontinent, resulting in a northerly flow into Gauteng (compare with Fig. 3c). At $700 \mathrm{hPa}$, there is strong northwesterly moisture flux into Gauteng around the anticyclone centred over Zimbabwe. At $500 \mathrm{hPa}$, Gauteng lies east of the major trough line, which displaces the continental high that is usually located over Botswana, resulting in fairly large values of relative vorticity advection and the consequential upward motion (Holton, 1992) in the mid-troposphere (not shown). This level of the atmosphere is also colder than the CLIM October months (Fig. 3a) with tight $500 \mathrm{hPa}$ temperature gradients in the vicinity of Gauteng. Considering the wind shear over Gauteng (Fig. 3c) as well, heavy rainfall in October develops in an atmosphere with clear baroclinic characteristics. Section 5.2 will show how the atmosphere in early summer is conditionally unstable, with large values of wind shear. 


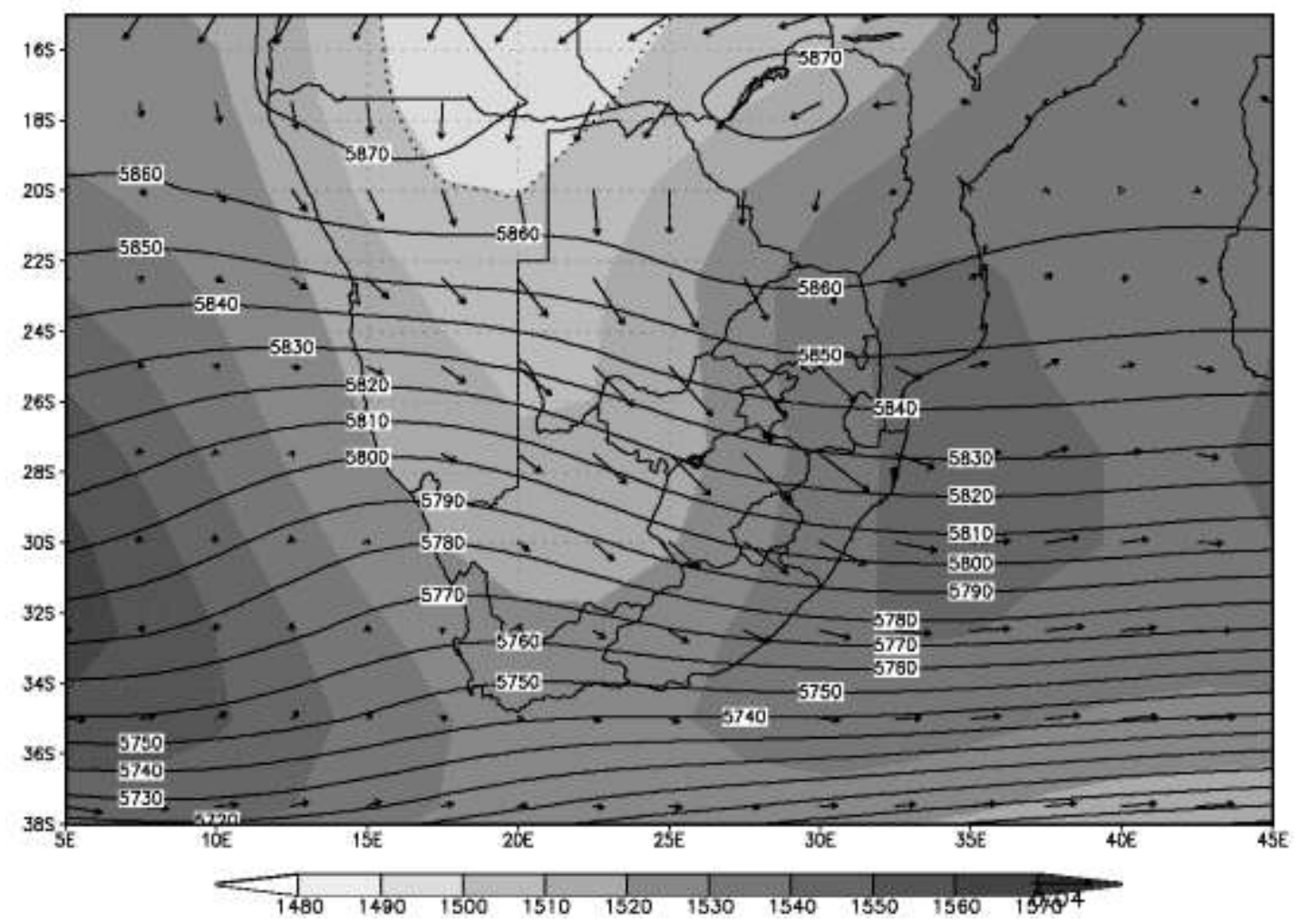

Figure 2a: Monthly mean $850 \mathrm{hPa}$ (shaded) and $500 \mathrm{hPa}$ (contours) geopotential heights for HEAVY October months. The arrows are moisture flux vectors at $700 \mathrm{hPa}$.

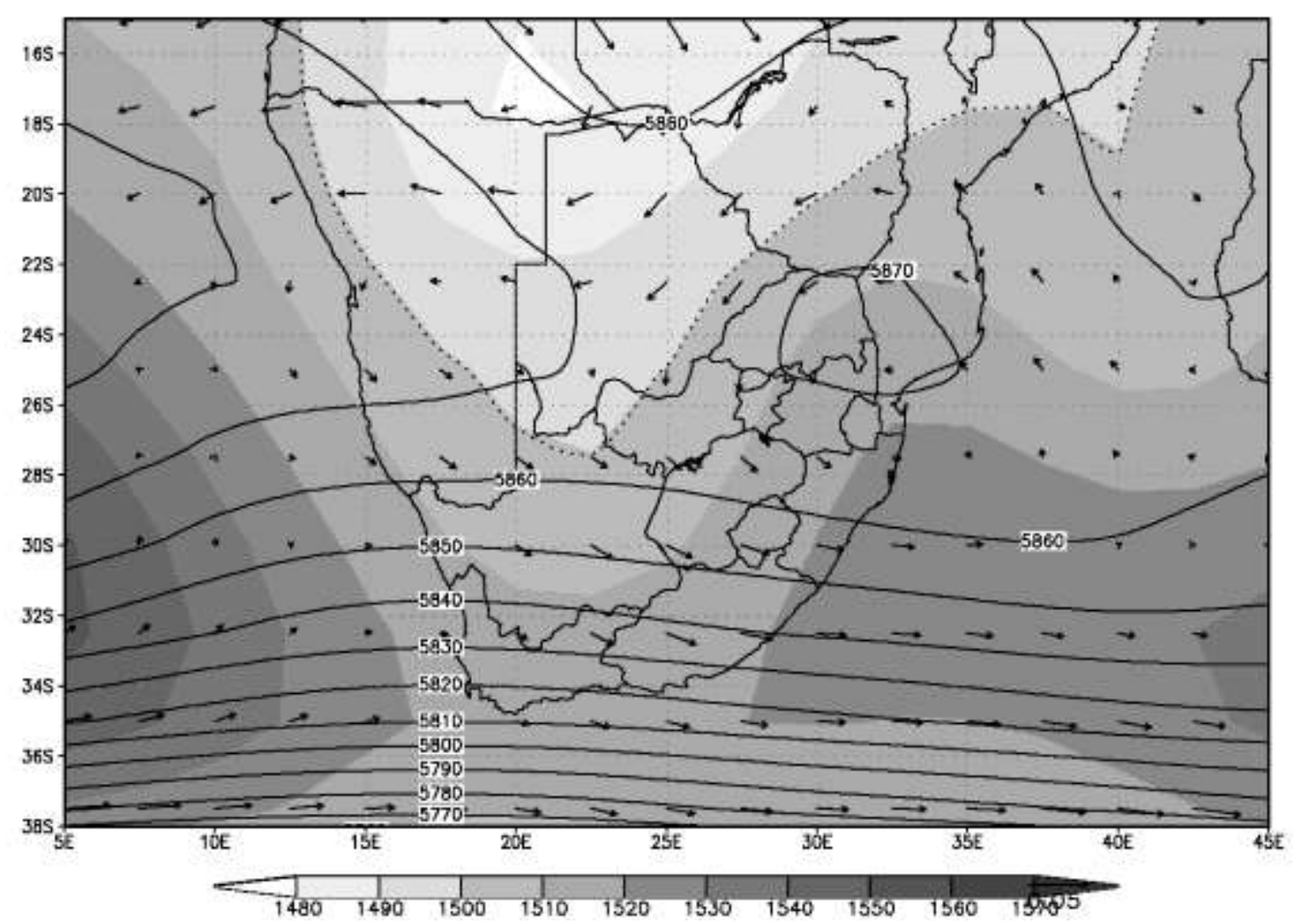

Figure 2b: Same as Figure 2a, but for HEAVY February months. 
In February, the surface trough for HEAVY days is deeper and situated further east over the central interior than in October, while the $\mathrm{IOH}$ is weaker and located further south. A broad low is present over the Angola/Namibia border and Hart et al. (2010) highlighted the importance of this feature when heavy rainfall occurs over the summer rainfall area of South Africa. At $700 \mathrm{hPa}$, the flow into the southern subcontinent originates over the warm Mozambique Channel, causing a weak northerly flow into Gauteng as the air circulates around the high pressure located over north-eastern South Africa. This moisture influx results in relative humidity (RH) values, larger than $60 \%$ (Fig. 3b) in the lower troposphere. At $500 \mathrm{hPa}$, the continental high pressure system is split into two, resulting in a broad trough northwest of Gauteng. The trough responsible for heavy rainfall in February stands approximately upright in height, and is warm cored in the upper troposphere (Fig. 3a). The winds throughout the entire troposphere are light with small values of wind shear (Fig. 3c). This circulation resembles the continental tropical low described by Dyson and Van Heerden (2002).

\subsection{Sounding-derived parameters}

The change in the circulation regime of the atmosphere during summer is further illustrated by sounding-derived parameters. This section will emphasise the change in the values of the parameters during summer and will isolate those parameters that distinguish the conditions during HEAVY events from the climatological mean (CLIM). It will also illustrate how the parameters that identify heavy rainfall change during the season.

\section{a. Temperatures, humidity and winds}

The temperature, dew point temperature and zonal and meridionial winds were interpolated to 850 (surface), $800,700,600,500,400$ and $300 \mathrm{hPa}$ pressure levels for every sounding. Monthly average values were then calculated on each of these pressure levels and the results 


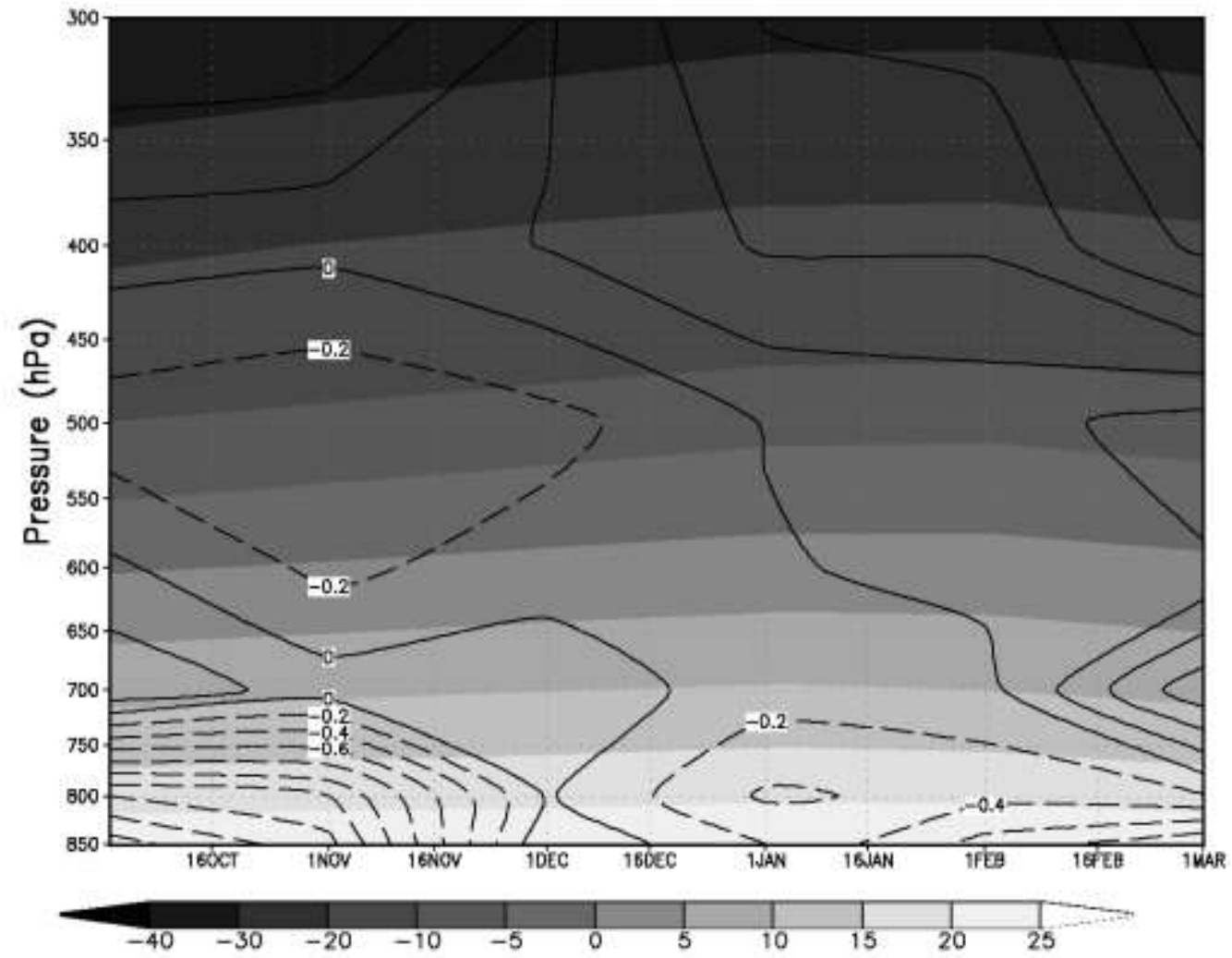

Figure 3a: Vertical profile of the monthly CLIM temperatures $\left({ }^{\circ} \mathrm{C}\right)$ for October to March at Irene at 1200 UTC (shaded). The anomalies for HEAVY soundings are shown in contours.

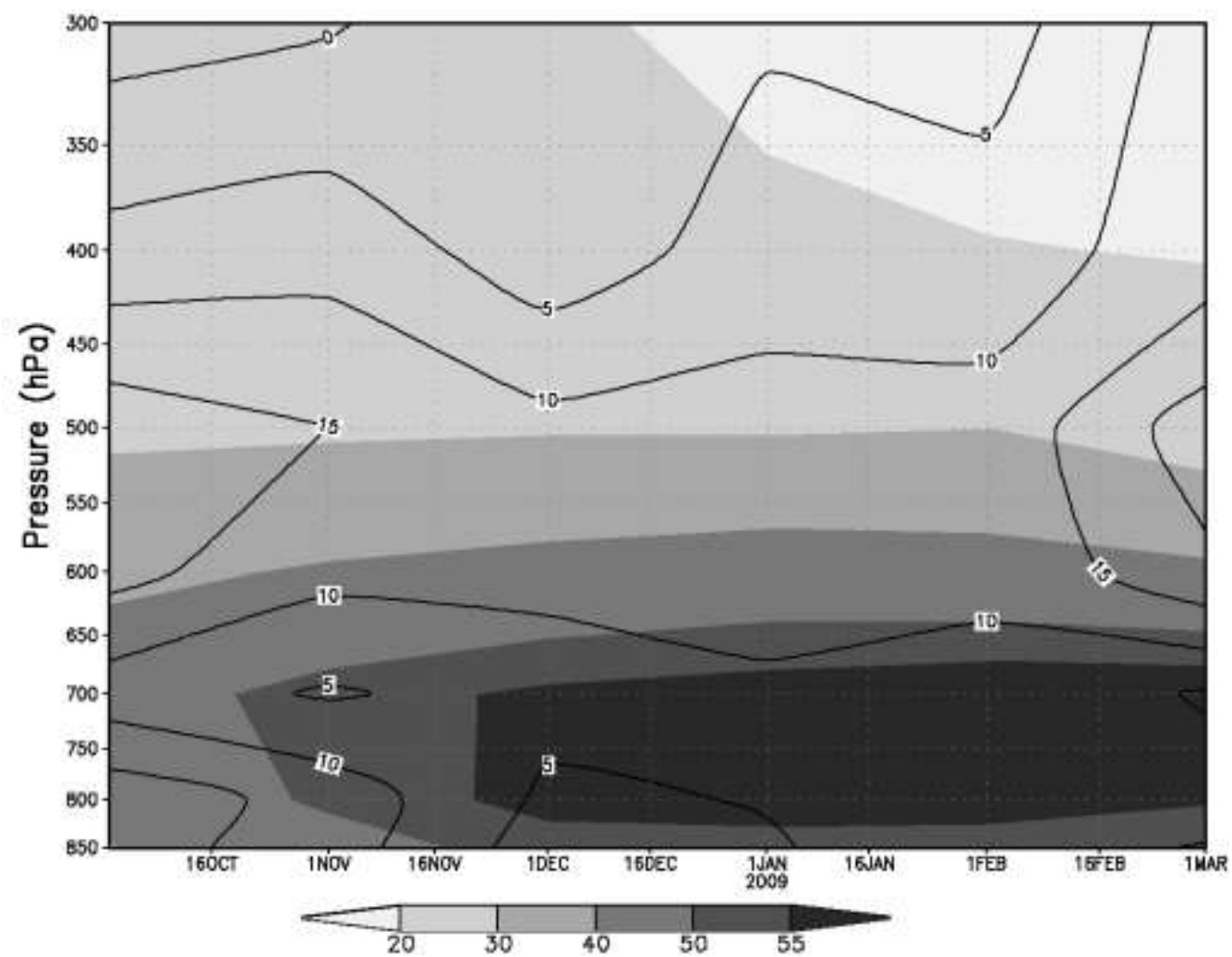

Figure 3b: Same as Figure 3a, but for relative humidity (\%). 


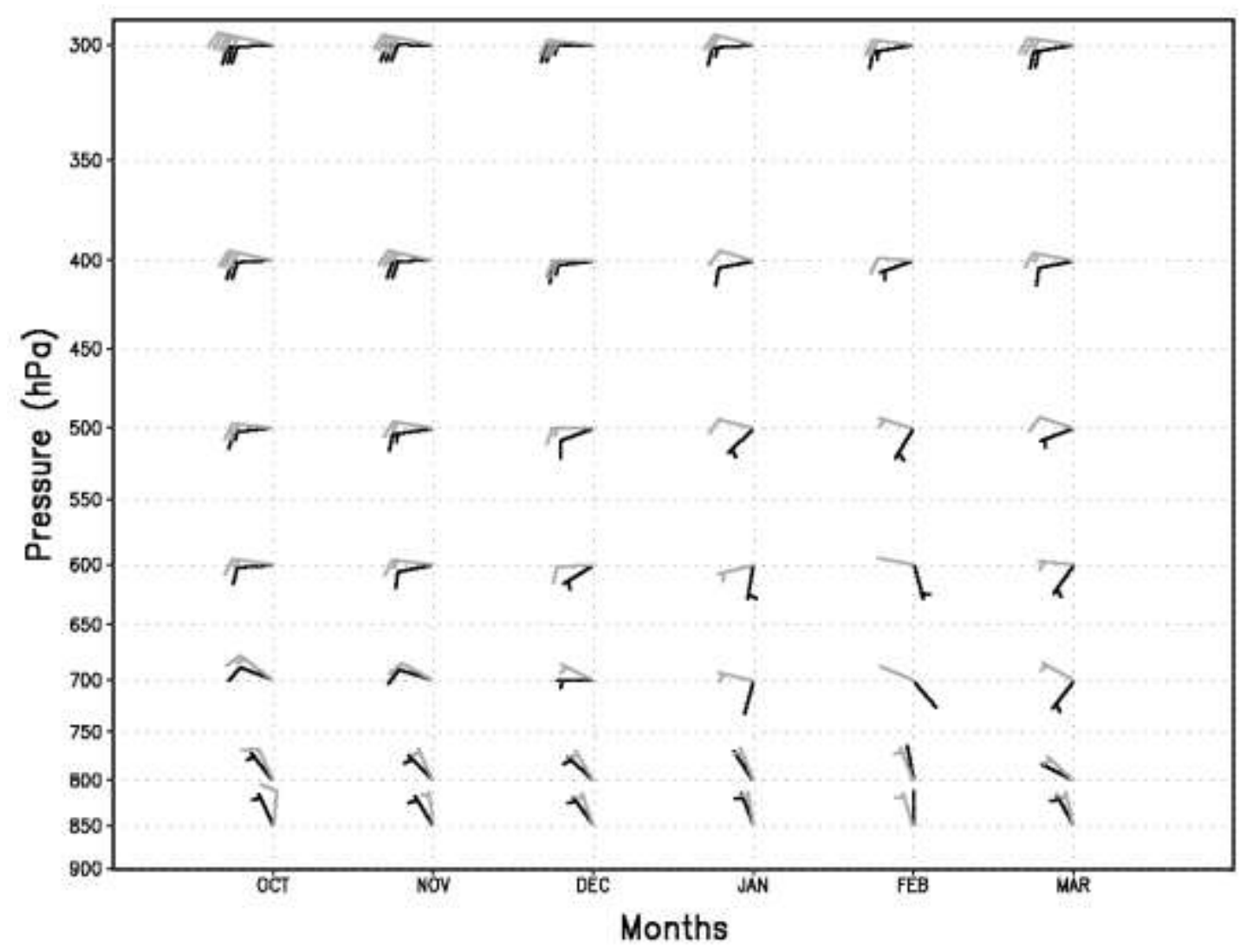

Figure 3c: Vertical profile of the monthly mean wind direction and speed for October to March at Irene at 1200 UTC. Short barbs represent wind strengths of $2.5 \mathrm{~ms}-1$ and long barbs $5 \mathrm{~ms}-1$. Black barbs are the CLIM winds and grey mean HEAVY winds.

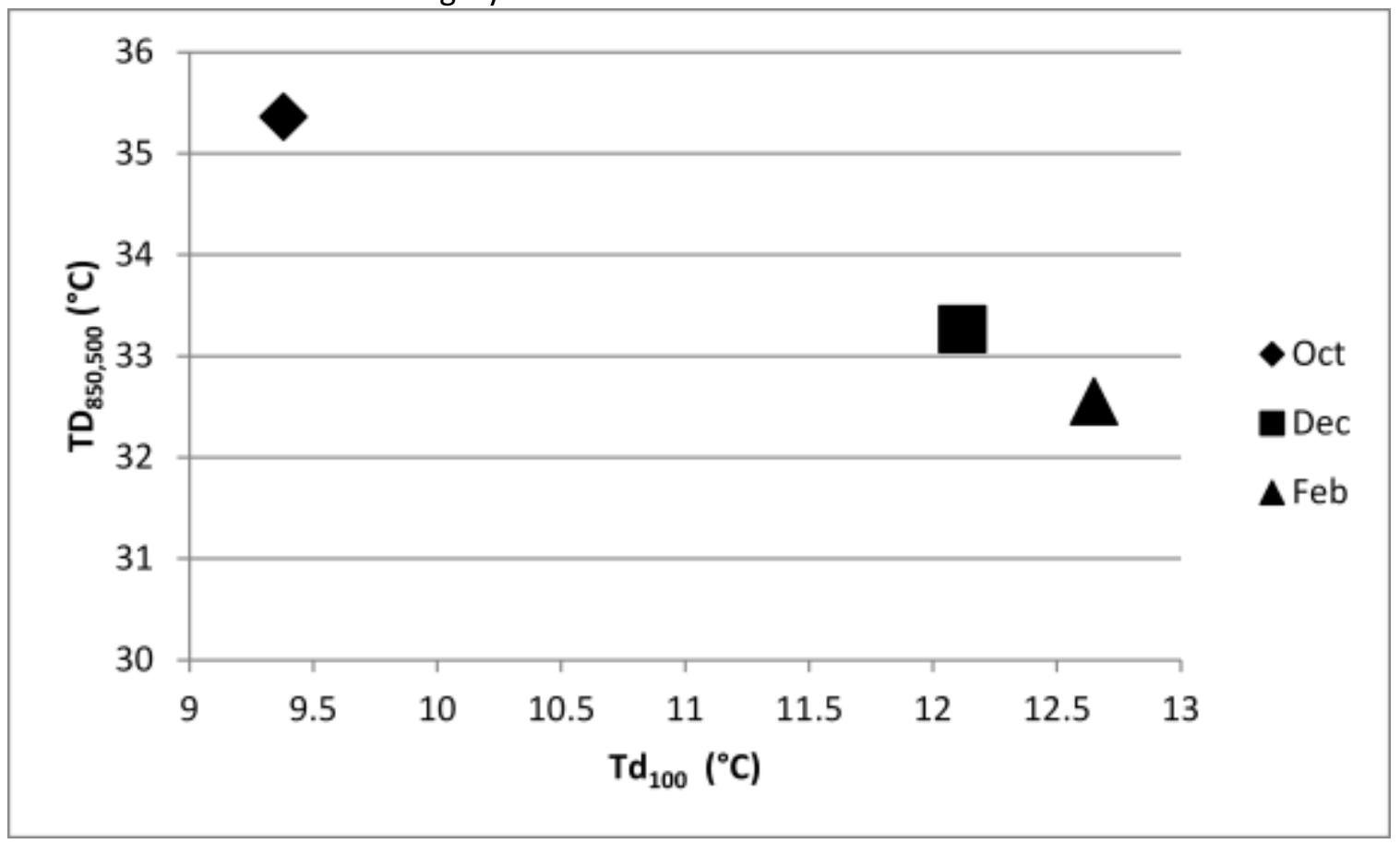

Figure 4: Scatter plot of the average 1200 UTC mean layer dew point temperature $\left(\operatorname{Td}_{100}\right)$ and the temperature difference from $850-500 \mathrm{hPa}\left(\mathrm{TD}_{850,500}\right)$ at Irene for October, December and February on all days when CAPE $>1000 \mathrm{Jkg}-1$. 
are displayed in vertical time section plots together with the anomalies when heavy rainfall occurs (Fig. 3a to Fig.3c).

The mean monthly tropospheric temperatures increase steadily during the summer season with the largest increase in the upper troposphere (Fig. 3a). There is a $5{ }^{\circ} \mathrm{C}$ increase in temperatures at $300 \mathrm{hPa}$ from October to February. This seasonal increase in mean upper tropospheric temperatures is similar to the increase in the temperatures of the tropical tropopause (Reid and Gage, 1981). In the lower troposphere, the mean temperatures increase $2{ }^{\circ} \mathrm{C}$ on average from October to January, decreasing slightly in February and March. From the surface to $600 \mathrm{hPa}$, the highest seasonal temperatures occur in January, but at pressures lower than $600 \mathrm{hPa}$ the highest temperatures are recorded in February. In Table 3, the increase in the monthly CLIM values of the column average $850-700 \mathrm{hPa}\left(\mathrm{T}_{850,700}\right)$ and the $500-300 \mathrm{hPa}$ $\left(T_{500,300}\right)$ temperatures are also shown. The $T_{850,700}$ values increase by about $1{ }^{\circ} \mathrm{C}$ from October to January, and the $T_{500,300}$ values increase by close to $5{ }^{\circ} \mathrm{C}$ from October to February. The noteworthy increase in mid-tropospheric temperatures during the season, with relatively small increases in temperatures near the surface, will necessarily also influence the monthly mean temperature lapse rates, and therefore the mean state of the conditional instability of the atmosphere when heavy rainfall occurs. The atmosphere is said to be conditionally unstable when the atmospheric temperature lapse rate is steeper than a moist adiabat, but less steep than a dry adiabat (Doswell et al., 1985). Table 3 depicts how the CLIM values of the temperature difference between $850-500 \mathrm{hPa}\left(\mathrm{TD}_{850,500}\right)$ decrease during the season, indicating a general decrease in the conditional instability of the atmosphere. Instability indices such as the $K$-Index $(\mathrm{KI})$ and the Showalter Index (SI), which rely in one way or another on temperature lapse rates, will also be influenced by this decrease as summer progresses. 
Table 3: Listing of the monthly mean values of the sounding parameters. $\left({ }^{*}\right.$ indicates that the difference between the sample means of the HEAVY and CLIM groups were not significant up to at least the $10 \%$ level.) The unequal variance $t$-test is used.

\begin{tabular}{|c|c|c|c|c|c|c|c|}
\hline & & October & November & December & January & February & March \\
\hline & CLIM & 16.9 & 17.1 & 17.4 & 17.9 & 17.8 & 16.9 \\
\hline$T_{850,700}$ & HEAVY & 15.5 & 15.7 & $17.5^{*}$ & $17.9 *$ & $17.7^{*}$ & $16.8^{*}$ \\
\hline \multirow[b]{2}{*}{$T_{500,300}$} & CLIM & -22.2 & -20.7 & -19.1 & -17.8 & -17.5 & -19.0 \\
\hline & HEAVY & $-21.9 *$ & $-20.5^{*}$ & -18.5 & $-17.4^{*}$ & $-17.4^{*}$ & -18.3 \\
\hline \multirow[b]{2}{*}{$\mathrm{TD}_{850,700}$} & CLIM & 16 & 15 & 15 & 15 & 15 & 15 \\
\hline & HEAVY & 14 & 14 & $15^{*}$ & $15^{*}$ & $15^{*}$ & 14 \\
\hline \multirow[b]{2}{*}{$T D_{850,500}$} & CLIM & 34 & 33 & 32 & 32 & 31 & 31 \\
\hline & HEAVY & 33 & 32 & $33^{*}$ & $31 *$ & $31 *$ & $30 *$ \\
\hline \multirow[b]{2}{*}{$\mathrm{Td}_{500}$} & CLIM & -30 & -29 & -27 & -26 & -26 & -29 \\
\hline & HEAVY & -23 & -22 & -21 & -20 & -21 & -19 \\
\hline \multirow[b]{2}{*}{ PW } & CLIM & 16 & 19 & 21 & 23 & 22 & 20 \\
\hline & HEAVY & 21 & 22 & 24 & 26 & 26 & 25 \\
\hline \multirow[b]{2}{*}{$\mathrm{Td}_{100}$} & CLIM & 5 & 8 & 10 & 11 & 11 & 9 \\
\hline & HEAVY & 10 & 11 & 12 & 12 & 13 & 11 \\
\hline \multirow[b]{2}{*}{$W_{300}$} & CLIM & 19 & 18 & 15 & 12 & 11 & 14 \\
\hline & HEAVY & 23 & 22 & $16^{*}$ & $13^{*}$ & $12^{*}$ & $15^{*}$ \\
\hline \multirow[b]{2}{*}{$\mathrm{BS}_{850,700}$} & CLIM & 5.0 & 4.6 & 4.1 & 4.0 & 3.9 & 4.1 \\
\hline & HEAVY & 6.6 & 6.2 & $4.4^{*}$ & $3.9^{*}$ & $3.5^{*}$ & $4.3^{*}$ \\
\hline \multirow[b]{2}{*}{$\mathrm{BS}_{850,400}$} & CLIM & 13 & 12 & 10 & 8 & 7 & 9 \\
\hline & HEAVY & 17 & 15 & $11^{*}$ & $8^{*}$ & 9* & $10^{*}$ \\
\hline \multirow[b]{2}{*}{$V_{800,600}$} & CLIM & -1.4 & -1.1 & -0.2 & 0.6 & 0.8 & 0.8 \\
\hline & HEAVY & -3.6 & -3.0 & -1.9 & --0.6 & --0.8 & -1.0 \\
\hline \multirow[b]{2}{*}{$\theta_{\mathrm{e} 100}$} & CLIM & 333 & 338 & 342 & 345 & 344 & 340 \\
\hline & HEAVY & 338 & 341 & 345 & 347 & 347 & 343 \\
\hline \multirow[b]{2}{*}{$\Delta \boldsymbol{\theta}_{\mathrm{e} 850,400}$} & CLIM & 10 & 13 & 17 & 18 & 16 & 14 \\
\hline & HEAVY & 15 & 17 & 19 & 19 & 18 & $15^{*}$ \\
\hline \multirow[b]{2}{*}{$\Delta \theta_{\mathrm{e} 850,500}$} & CLIM & 14 & 18 & 21 & 22 & 21 & 18 \\
\hline & HEAVY & 18 & 20 & $23 *$ & $23^{*}$ & $22^{*}$ & $19 *$ \\
\hline \multirow[b]{2}{*}{ CAPE } & CLIM & 467 & 723 & 828 & 812 & 643 & 541 \\
\hline & HEAVY & 999 & 1140 & 1138 & $855 *$ & 923 & $679 *$ \\
\hline \multirow[b]{2}{*}{ SI } & CLIM & -0.8 & -1.6 & -2.1 & -1.9 & -1.5 & -0.9 \\
\hline & HEAVY & -3.6 & -3.5 & -3.5 & -2.7 & -2.5 & -2.0 \\
\hline \multirow[b]{2}{*}{ KI } & CLIM & 29 & 34 & 36 & 37 & 37 & 35 \\
\hline & HEAVY & 36 & 38 & 40 & 41 & 41 & 38 \\
\hline \multirow[b]{2}{*}{ EKI } & CLIM & -2 & 2 & 4 & 5 & 4 & 1 \\
\hline & HEAVY & 10 & 10 & 11 & 12 & 10 & 12 \\
\hline \multirow[b]{2}{*}{ WCD } & CLIM & 49 & 90 & 119 & 132 & 131 & 115 \\
\hline & HEAVY & 116 & 127 & $125^{*}$ & 142 & 155 & 142 \\
\hline
\end{tabular}


For HEAVY soundings, the temperatures in the mid-troposphere $(600-400 \mathrm{hPa})$ are slightly lower than the CLIM values in early summer (October to December), but higher in the late summer months (January to March) (Fig. 3a). However, temperature deviations are very small, except in the surface layers. At the surface, HEAVY events are associated with below normal temperatures for all months. These deviations are larger in early summer. The monthly mean HEAVY values of $T_{850,700}$ (Table 3 ) are significantly less than the CLIM values in October and November only. The mean monthly HEAVY values of $T_{500,300}$ are slightly lower than the CLIM values in all months, but these differences are significant in December and March only .

Fig. $3 \mathrm{~b}$ depicts the increase in monthly CLIM RH values during the summer season, so that in the last three months of the season, the $\mathrm{RH}$ values exceed $55 \%$ in the lowest $3 \mathrm{~km}$ of the atmosphere. Heavy rainfall over Gauteng in late summer therefore develops in an atmosphere where the mean near surface $\mathrm{RH}$ values are already quite high and with only about a $5 \%$ increase during HEAVY events. For HEAVY soundings, the monthly RH values are higher than the CLIM values with the largest increases in the $600-500 \mathrm{hPa}$ layer, where the values are more than $10 \%$ higher (Fig. 3b).

The mean monthly $500 \mathrm{hPa}$ dew point temperatures $\left(\mathrm{Td}_{500}\right)$ for HEAVY soundings are significantly higher than CLIM soundings in all summer months (Table 3). In December, January and February, HEAVY $\operatorname{Td}_{500}$ values are 5 to $6^{\circ} \mathrm{C}$ higher than CLIM values, but 7 to $9^{\circ} \mathrm{C}$ higher in October, November and March. Heavy rainfall during early summer is caused by weather systems that significantly increase the moisture in the atmosphere, while in late summer there are only slight moisture increases, as abundant moisture is already available in Gauteng. This is also illustrated in Fig. 2a and Fig. 2b, where heavy rainfall over Gauteng in October is associated with strong northwesterly moisture flux, while for late summer HEAVY events, the moisture flux is much weaker. The monthly CLIM precipitable water (PW) values increase from 
16 to $23 \mathrm{~mm}$, while the mean monthly HEAVY values vary between 21 and $26 \mathrm{~mm}$ (Table 3). These differences are all significant. Note how the October HEAVY PW value $(21 \mathrm{~mm})$ is less than the CLIM value for January and February. Threshold values associated with heavy rainfall is dependent on the month.

The monthly CLIM wind strength decreases at all pressure levels from October to February. At $400 \mathrm{hPa}$, the CLIM wind strength decreases from about $13 \mathrm{~ms}^{-1}$ in October to $4 \mathrm{~ms}^{-1}$ in February (Fig. 3c). In January and February, the average CLIM wind speeds throughout the troposphere are very light and only at pressures lower than $400 \mathrm{hPa}$ does the wind speed exceed $5 \mathrm{~ms}^{-1}$. In February, the mean winds are less than $2.5 \mathrm{~ms}^{-1}$ from the surface to $500 \mathrm{hPa}$.

For HEAVY soundings, the winds are generally stronger than the CLIM soundings, with the largest differences in the upper troposphere (Fig. 3c). At $300 \mathrm{hPa}$, the mean HEAVY winds $\left(\mathrm{W}_{300}\right)$ are $4 \mathrm{~ms}^{-1}$ stronger than CLIM winds in October and November, but only by $1 \mathrm{~ms}^{-1}$ in late summer (Table 3). Ramaswamy (1956) was one of the first authors to elaborate on the importance of the subtropical jet in the development of large-scale convection. The strongerthan-average wind speeds in the upper troposphere associated with HEAVY soundings indicate that the jet stream also plays a role in heavy rainfall over Gauteng, but only in early summer. The $300 \mathrm{hPa}$ wind strength $\left(\mathrm{W}_{300}\right)$ for HEAVY soundings is significantly stronger than CLIM soundings in October and November only (Table 3). In February, from 700-500 hPa, the HEAVY wind strengths decrease to close to zero (Fig. 3c). These light winds will increase the precipitation rate of the convective cells that develop during these months (Doswell et al., 1996). Dyson (2009) has shown that heavy rainfall is more prevalent during January and February over Gauteng than during early summer.

The HEAVY shallow layer wind shear $\left(\mathrm{BS}_{850,700}\right)$ and the deep layer wind shear $\left(\mathrm{BS}_{850,400}\right)$ is also significantly larger than the CLIM values in October and November only (Table 3). The mean 
HEAVY $\mathrm{BS}_{850,400}$ value in October and November $\left(15-17 \mathrm{~ms}^{-1}\right)$ is similar to the deep layer wind shear values that Craven and Brooks (2004) found to be associated with significant thunderstorms with strong winds and hail in the USA. In February, the CLIM and HEAVY values of the $\mathrm{BS}_{850,400}$ are equal to and less than half the HEAVY value in October. The large wind shear values in October and the small values in February are again indicative of how the characteristics of the atmosphere change to tropical during summer. In late summer, the absence of wind shear buoyancy is the dominant factor in the development of deep moist convection, and the light winds increase the precipitation rate of convective cells (Doswell et al., 1996). Wind shear organises convection in lines (e.g. squall lines) or, if the relationship between buoyancy and wind shear is optimal, supercells may develop. Some $24 \%$ of HEAVY days in early summer have wind shear values larger than $15 \mathrm{~ms}^{-1}$. This figure is only $7 \%$ in late summer. Only during early summer is heavy rainfall associated with an atmosphere where conditions are conducive to the development of severe storms.

The monthly CLIM winds at pressure levels lower than $700 \mathrm{hPa}$ are mostly westerly in the early summer and increase in strength with altitude (Fig. 3c). From 500 to $400 \mathrm{hPa}$, the CLIM winds back slightly from October to December, resulting in southwesterly winds at these pressure levels in late summer. At $700 \mathrm{hPa}$, the monthly CLIM winds back during the season to southerly and even southeasterly in February. At the surface, the winds are very light and change in direction from northwesterly to northerly during the season.

The wind direction for HEAVY soundings generally veers in respect to the CLIM wind direction (Fig. 3c). Differences between the wind direction for CLIM soundings and HEAVY soundings increase as the season progresses. From the surface to $500 \mathrm{hPa}$ in early summer, the wind directions for HEAVY soundings are west-north-westerly with an increasing northerly component close to the surface. From Fig. $2 a$ and $2 b$, as well as Fig. $3 c$, it becomes clear that 
when heavy rainfall occurs over Gauteng, the mean wind direction is northwesterly through most of the troposphere. A new wind parameter was tested to distinguish HEAVY and CLIM soundings, namely the average meridionial wind component in the $800-600 \mathrm{hPa}$ layer $\left(\mathrm{V}_{800,600}\right)$. The HEAVY $V_{800,600}$ is northerly in early summer (the same as for CLIM), but greater in magnitude (Table 3). In late summer, the magnitude of CLIM and HEAVY $\mathrm{V}_{800,600}$ values are similar, but with northerly HEAVY winds and southerly CLIM winds. The difference in $\mathrm{V}_{800,600}$ values between HEAVY and CLIM are significant for all months.

\section{b. Instability parameters}

Several instability parameters exist, which provide information about the convective or conditional instability of the atmosphere. A few of these parameters are discussed here and emphasis is placed on the change in value of these parameters during the season and their relationship to each other.

The equivalent potential temperature $\left(\theta_{\mathrm{e}}\right)$ is often used to determine the convective or potential instability of a layer in the atmosphere (Schultz et al., 2000). The atmosphere is said to be convectively unstable if $\Delta \theta_{\mathrm{e}}>0$ through a sufficiently deep layer in the atmosphere. Furthermore, $\theta_{\mathrm{e}}$ can be used to identify air mass changes (Houston and Wilhelmson, 2012). The mean monthly average $\theta_{\mathrm{e}}$ values in the lowest $100 \mathrm{hPa}\left(\theta_{\mathrm{e}} 100\right)$ increase from $333 \mathrm{~K}$ in October to $345 \mathrm{~K}$ in January. The equivalent potential temperature is a function of both moisture and temperature, and the increase in $\operatorname{CLIM} \Theta_{\mathrm{e} 100}$ values during summer reflects the increase in temperature and moisture during the same period. Values for $\theta_{\mathrm{e}} 100$ are higher for HEAVY soundings than CLIM soundings, and these differences are significant for all months.

The CLIM values of $\Delta \Theta_{\mathrm{e} 850,400}$ increase by $8 \mathrm{~K}$ during the summer (Table 3). The mean state of the atmosphere in which heavy rainfall develops therefore becomes increasingly convectively unstable during summer. For HEAVY soundings, the values of $\Delta \Theta_{\mathrm{e} 850,400}$ are higher than the 
CLIM values for all six months, but the difference is not significant in March. The differences in monthly mean values of $\Delta \Theta_{\mathrm{e}} 850,400$ between CLIM and HEAVY soundings are largest (4-5 K) in October and November. Cohen et al. (2007) found that the $0-7 \mathrm{~km} \Delta \theta_{\mathrm{e}}$, as well as the $\Delta \Theta_{\mathrm{e}}$ between the maximum and minimum $\theta_{\mathrm{e}}$ values in the troposphere, discriminated the best between weak and severe mesoscale convective systems. Here, it was found that the $\Delta \Theta_{\mathrm{e} 850,400}$ was the only $\Delta \theta_{\mathrm{e}}$ that distinguished significantly between CLIM and HEAVY soundings for all months (except March). The $\Delta \Theta_{\mathrm{e}} 850,500$ difference between CLIM and HEAVY soundings was significant in October and November only, while the $\Delta \theta_{\mathrm{e}}$ between the maximum and minimum $\Theta_{\mathrm{e}}$ did not discriminate between HEAVY and CLIM soundings in any of the summer months.

During the progression of the summer season, the atmosphere over Gauteng becomes less conditionally unstable (temperature difference (TD) in Table 3 ) and increasingly convectively unstable $\left(\Delta \theta_{\mathrm{e}}\right.$ in Table 3$)$. In early summer, the TD clearly distinguishes between HEAVY and CLIM soundings, as do the $\Delta \Theta_{\mathrm{e}}$ values. Of all the temperature and $\Theta_{\mathrm{e}}$ lapse rates investigated in this research, only the mean $\Delta \theta_{\mathrm{e}} 850,400$ was capable of distinguishing significantly between HEAVY and CLIM soundings during December, January and February.

Cohen et al. (2007) state that $\Delta \theta_{\mathrm{e}}$ and CAPE represent similar physical processes in the atmosphere and both provide information about the atmospheric instability (Shultz et al., 2000). The relationship between $\Delta \Theta_{\mathrm{e}}$ and CAPE is also reflected in the Irene sounding data as the correlation coefficient between CAPE and $\Delta \theta_{\mathrm{e}} 850,400$ is 0.71 during summer. CAPE is essentially a measure of the conditional instability of the atmosphere and is a function of the lifted parcel moisture content and atmospheric lapse rate. However, the correlation coefficient between CAPE and $\mathrm{TD}_{850,500}$ is only 0.23 at Irene in summer and 0.53 between CAPE and $\mathrm{Td}_{100}$. Fig. 4 is a scatter plot of the average $T_{d}$ and $T D_{850,500}$ on all days when CAPE $>1000 \mathrm{Jkg}^{-1}$. In October, CAPE $>1000 \mathrm{~J} \mathrm{~kg}^{-1}$ is associated with relatively low dew point temperatures (Td), but 
with large $\mathrm{TD}_{850,500}$ values. In February, when CAPE $>1000 \mathrm{Jkg}^{-1}$, the surface dew point temperatures are higher than in October and the $\mathrm{TD}_{850,500}$ values are lower. At Irene in summer, CAPE values are influenced by both the temperature lapse rate, and the low level moisture content and the relative contribution of these variables to large CAPE values changes during the season. From Table 3, it can be seen that the maximum monthly mean CLIM CAPE value occurs in December. Fig. 4 indicates that in December for CAPE $>1000 \mathrm{Jkg}^{-1}$, the mean $\mathrm{Td}_{100}$ is above $12{ }^{\circ} \mathrm{C}$, but with $\mathrm{TD}_{850,500}$ still relatively large. In December, the contribution to CAPE of both the temperature lapse rate and moist parcel maximises. This is further illustrated in Table 3, which indicates that the CLIM values of $\operatorname{Td}_{100}$ increases by $5{ }^{\circ} \mathrm{C}$ from October to December, while the $\mathrm{TD}_{850,500}$ values decrease by $2{ }^{\circ} \mathrm{C}$ during the same period.

HEAVY monthly mean CAPE values are larger than CLIM values for all the months, but not significantly so in January and March (Table 3). HEAVY sounding in early summer has mean monthly CAPE values $>1000 \mathrm{~J} \mathrm{~kg}^{-1}$, while the mean value in late summer is $<1000 \mathrm{~J} \mathrm{~kg}^{-1}$.

One of the advantages of using CAPE as a convective index is that it provides a measure of stability integrated over the depth of the sounding, as opposed to the Showalter Index (SI) or $K$-Index (KI) (for example) that uses data from only a few mandatory levels. Nevertheless, the SI is highly correlated with CAPE and at Irene in summer, the correlation coefficient between CAPE and SI is -77. Similar to CAPE, the CLIM values for the SI reach their most favourable value during December months (Table 3). In early summer, the mean monthly SI value for HEAVY soundings is about $-3.5^{\circ} \mathrm{C}$ and in late summer the SI varies between -2 and $-2.7^{\circ} \mathrm{C}$.

The $\mathrm{KI}$ is used to identify convective and heavy-rain-producing environments (Henry, 2000) and comprises a temperature difference term $\left(\mathrm{TD}_{850,500}\right)$, as well as terms that deal with surface and mid-level moisture (Table 1). The monthly CLIM KI values change from 29 to $37^{\circ} \mathrm{C}$ during summer. Mean monthly values of $\mathrm{TD}_{850,500}$ increase only slightly during summer months, but 
the surface $(850 \mathrm{hPa})$ and $700 \mathrm{hPa}$ dew point temperatures increase by $6{ }^{\circ} \mathrm{C}$ (not shown). The increase in KI values during the season can therefore largely be attributed to the increase in the moisture content of the atmosphere. From December to March, the CLIM KI values are higher than the proposed $35{ }^{\circ} \mathrm{C}$ threshold value, which is associated with heavy rainfall over the USA (De Rubertis, 2006). Mean HEAVY KI values are larger than the CLIM values and $40{ }^{\circ} \mathrm{C}$ and above in December, January and February. The differences between CLIM and HEAVY soundings are significant for all months.

The Elevated $K$-Index (EKI) is an attempt to take the height of the interior plateau of South Africa into consideration, and was first proposed by Todd (2010). The interior of South Africa lies close to $1500 \mathrm{~m}$ above mean sea level and the surface pressures are close to $850 \mathrm{hPa}$ in Gauteng. In EKI, all the pressure levels (except $500 \mathrm{hPa}$ ) were adapted downward from the KI by $100-150 \mathrm{hPa}$. Here $\mathrm{TD}_{700,500}$ helps to determine the conditional instability of the atmosphere. In October, the mean EKI value is less than zero due to the dry conditions in the $\pm 200 \mathrm{hPa}$ above ground level (Fig. 3b). The mean CLIM EKI value increases to $5^{\circ} \mathrm{C}$ in January as the moisture in the atmosphere increases. HEAVY EKI values vary between 10 and $12{ }^{\circ} \mathrm{C}$ during the summer and the differences between the CLIM and HEAVY soundings are significant for all months.

The warm cloud depth (WCD) is the difference in pressure between the lifted condensation level (LCL) and the freezing level $\left(0^{\circ} \mathrm{C}\right.$ isotherm). If a cloud exists in this layer, collision coalescence is the dominant process for precipitation droplet growth (Market et al., 2003). Schumacher and Johnson (2008) discuss how the WCD is one of the ingredients for high precipitation rates. During summer, as it becomes warmer and moister, the CLIM values of the WCD increase and more than double from October to January. HEAVY WCD values are significantly larger than CLIM values for all the months, except December. The differences 


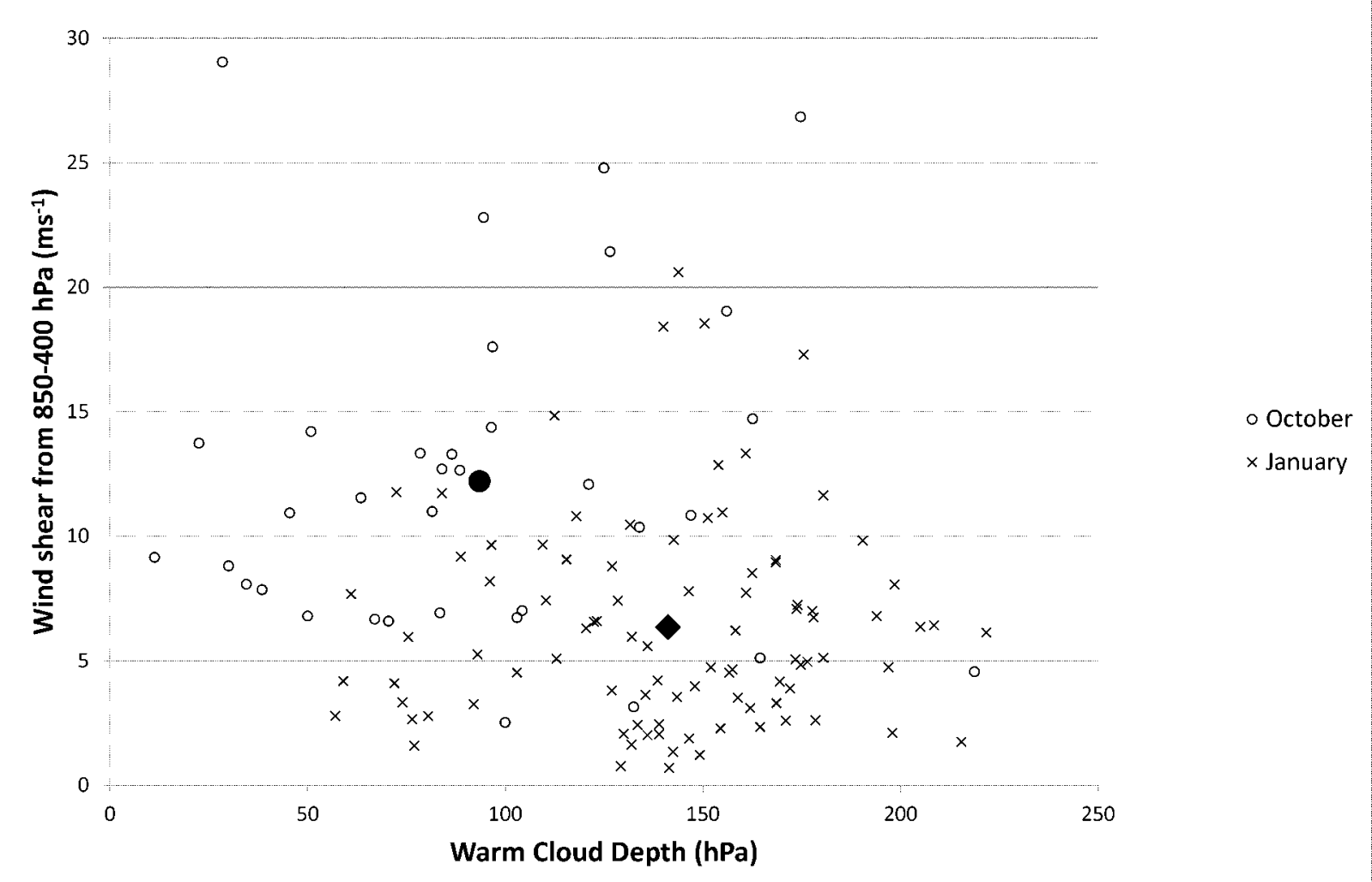

Figure 5: Scatter plot of the mean 1200 UTC warm cloud depth (WCD) and 850-400 hPa wind shear $\left(B S_{850,400)}\right.$ at Irene for HEAVY days in October and January. The solid circle is the mean October value for all HEAVY days and the solid diamond for all HEAVY January days. 
between the monthly CLIM and HEAVY sounding values decrease to less than $15 \mathrm{hPa}$ in December and February. In late summer, the winds throughout the troposphere become very light as the WCD increases. Fig. 5 examines the relationship between the $W C D$ and $\mathrm{BS}_{850,400}$ in October and January. In October, the WCD is smaller with larger values of $\mathrm{BS}_{850,400}$. In January, the $\mathrm{WCD}$ increases in value and the $\mathrm{BS}_{850,400}$ decreases. In early summer, $62 \%$ of heavy rainfall events have $W C D>100 \mathrm{hPa}$, and in late summer this percentage rises to $84 \%$. In early summer, the atmospheric conditions are conducive to the development of severe storms, while in late summer, slow-moving, precipitation-efficient convective storms cause heavy rainfall.

\section{Summary and Conclusions}

More than 30 austral summers of 1200 UTC SAWS Irene weather office upper air data were obtained and put through a vigorous quality control procedure, similar to the process described by Durre et al. (2006). These data were then used to create a monthly climatology of the vertical profile of basic variables, as well as sounding-derived parameters over Gauteng. A striking feature of the seasonal variation of these parameters is how the atmosphere changes from one with a very distinct extra-tropical nature in October, to one that is clearly tropical in February. This is most evidently demonstrated by the increase in temperature throughout the troposphere and the decrease in wind strength and vertical wind shear during the season. In February, the average wind speed is less than $2.5 \mathrm{~ms}^{-1}$ from the surface up to $500 \mathrm{hPa}$. The seasonal increase in temperature is higher at lower pressures than at higher pressures closer to the ground. This, in turn, influences the conditional instability of the atmosphere, and parameters that employ temperature lapse rates as an ingredient become less useful to identify heavy rainfall, especially in late summer. In late summer, using parameters that 
identify the convective instability in the atmosphere is more useful, such as the change of equivalent potential temperature with height $(\Delta \theta e)$. Convective variables, such as CAPE and the SI reach maximum favourable values in December months.

The assumption is made that the 1200 UTC Irene soundings represents the atmosphere over Gauteng prior to the onset of convection. A limitation of this study is that we do not have complete confidence that the 1200 UTC sounding represents the 24-hour rainfall. Nevertheless, days when the daily rainfall exceeded $50 \mathrm{~mm}$ at a station over Gauteng (HEAVY) were compared to the climatological mean (CLIM). Similar to the results of Harnack et al. (1998) the sounding parameters that best distinguish between CLIM and HEAVY soundings are those that provide information about the moisture content of the atmosphere. The mean layer, $500 \mathrm{hPa}$ dew point temperatures and precipitable water distinguish significantly between CLIM and HEAVY soundings for all months. The only other parameters that distinguish between CLIM and HEAVY soundings for all months are the average meridionial wind direction in the 800 to $600 \mathrm{hPa}$ layer $\left(\mathrm{V}_{800,600}\right)$, the mean layer $\Theta e$ value, the $\mathrm{SI}$, the $\mathrm{KI}$ and the EKI. However, critical values associated with heavy rainfall for all these parameters change month by month.

In October and November, heavy rainfall over Gauteng is associated with atmospheric conditions that are conducive to the development of severe storms (i.e. large values of wind shear and CAPE (Doswell and Rasmussen (1994) and Duplika and Reuter (2006a)). The wind shear values in October and November are similar to the values associated with thunderstorms with strong winds and hail in the USA (Craven and Brooks, 2004). In early summer the upper tropospheric winds are stronger for HEAVY soundings, which may indicate the presence of a jet stream. The subtropical jet has been associated with the development of large-scale convection (Ramaswamy, 1956). The vertical temperature differences during early summer 
over Gauteng are significantly larger than CLIM soundings indicating increased conditional instability (Craven and Brooks, 2004). Heavy rainfall during early summer over Gauteng is the result of weather systems that cause the moisture to be significantly higher than the climatological mean.

During late summer, there is, on average, abundant moisture in circulation and the differences between CLIM and HEAVY values of the moisture variables are lower than in early summer. This is also true for the variables that use the equivalent potential temperature. The weather systems responsible for heavy rainfall in late summer cause a stronger than normal northwesterly wind, which increases the moisture content of the atmosphere slightly. In late summer, slow moving, precipitation efficient convective storms cause heavy rainfall. 


\section{REFERENCES}

Alexander WJR and Van Heerden J. 1991. Determination of the risk of widespread interruption of communications by floods. Department of Transport Research Project RDAC 90/16.

Beavon KSO. 2004. Johannesburg: The Making and Shaping of the City. UNISA Press: Pretoria, 373.

Berry GJ and Thorncroft CD. 2005. Case study of an intense African easterly wave. Monthly Weather Review 133: 752-766. DOI: http://dx.doi.org/10.1175/MWR2884.1

Bosart LF, Seimon A, Lapenta KD and Dickinson MJ. 2006. Supercell tornadogenesis over complex terrain: the Great Barrington, Massachusetts, tornado on 29 May 1995. Weather and Forecasting 21: 897-922. DOI: http://dx.doi.org/10.1175/WAF957.1.

Brimelow JC, Reuter GW and Poolman EP. 2002. Modeling Maximum Hail Size in Alberta Thunderstorms. Weather and Forecasting 17: 1048-1062. DOI: http://dx.doi.org/10.1175/15200434(2002)017\%3C1048:MMHSIA\%3E2.0.CO;2.

Brooks HE and Stensrud DJ. 2000. Climatology of heavy rain events in the United States from hourly precipitation observations. Monthly Weather Review 128: 1194-1201. DOI: http://dx.doi.org/10.1175/1520-0493(2000)128<1194:COHREI>2.0.CO;2.

Brooks HE, Doswell CA III and Cooper J. 1994. On the environments of tornadic and nontornadic mesocyclones. Weather and Forecasting 9: 606-618. DOI: http://dx.doi.org/10.1175/15200434(1994)009\%3C0606:OTEOTA\%3E2.0.CO;2.

Bunkers MJ, Klimowski BA, Zeitler JW, Thompson R and Weisman ML. 2002. The importance of parcel choice and the measure of vertical wind shear in evaluating the convective environment. Preprints, 21st Conference on Severe Local Storms, San Antonio, TX, American Meteorological Society, 379-382.

Chaudhari HS, Sawaisarje GK, Ranalkar MR and Sen PN. 2010. Thunderstorm over a tropical Indian station, Minicoy: Role of vertical wind shear. Journal of Earth System Science 119: 603-615. DOI: DOI:10.1007/s12040-010-0044-3.

Cohen AE, Coniglio MC, Corfidi SF and Corfidi SJ. 2007. Discrimination of mesoscale convective system environments using sounding observations. Weather and Forecasting 22: 1045-1062. DOI: http://dx.doi.org/10.1175/WAF1040.1

Costa S, Mezzasalma P, Levizzani V, Alberoni PP and Nanni S. 2001. Deep convection over Northern Italy: synoptic and thermodynamic analysis. Atmospheric Research 56: 73-88. DOI: 10.1016/S01698095(00)00091-0.

Covadonga P, Dario G, Stel F, Castro A and Fraile R. 2010. Maximum hailstone size: Relationship with meteorological variables. Atmospheric Research 96: 256-265. DOI: http://dx.doi.org/10.1175/WAF915.1.

Craven JP and Brooks HE. 2004. Baseline climatology of sounding-derived parameters associated with deep moist convection, National Weather Digest 28: 13-24.

Craven JP, Jewell RE and Brooks HE. 2002. Comparison between observed convective cloud-base heights and lifting condensation level for two different lifted parcels. Weather and Forecasting, 17: 885890. DOI: http://dx.doi.org/10.1175/1520-0434(2002)017<0885:CBOCCB>2.0.CO;2.

Daniel EZ. 2006. Forecasting mixed-layer height over complex terrain. Preprints of the 12th Conference on Mountain Meteorology. [Online]. Available: https://ams.confex.com/ams/pdfpapers/ 114269.pdf (Accessed on 22 January 2012). 
Darkow GL. 1969. An analysis over sixty tornado proximity soundings. Preprints, Sixth Conference on Severe Local Storms, Chicago, IL, American Meteorological Society, 218-221.

De Coning E, Forbes GS and Poolman EP. 1998. Heavy precipitation and flooding on 12-14 February 1996 over the summer rainfall regions of South Africa: Synoptic and Isentropic analyses. National Weather Digest 22: 25-36.

Department of Water Affairs (DWA). 2012. Hydrological Services - Surface water (data, dams, floods and flows). [Online]. Available: ahttp://www.dwaf.gov.za/Hydrology/Provincial\%20Rain/ Provincial\%20Rainfall.htm (Accessed 21 August 2012).

De Rubertis D. 2006. Recent trends in four common stability indices derived from U.S. radiosonde observations. Journal of Climate 19: 309-323. DOI: http://dx.doi.org/10.1175/JCLI3626.1.

Dimitrova T, Mitzeva R and Savtchenko A. 2009. Environmental conditions responsible for the type of precipitation in summer convective storms over Bulgaria. Atmospheric Research 93: 30-38. DOI: 0.1016/j.atmosres.2008.10.010

Doswell CA III and Rasmussen EN. 1994. The effect of neglecting the virtual temperature correction on CAPE calculations. Weather and Forecasting 9: 625-629. DOI: http://dx.doi.org/10.1175/15200434(1994)009\%3C0625:TEONTV\%3E2.0.CO;2.

Doswell CA III and Schultz DM. 2006. On the use of indices and parameters in forecasting severe storms. Electronic Journal Severe Storms Meteorology 1: 1-14.

Doswell CA III, Caracena F and Magnano M. 1985. Temporal evolution of 700-500-mb lapse rate as a forecasting tool - A case study. Preprints, 14th Conference on Severe Local Storms, Indianapolis, IN, American Meteorological Society, 398-401.

Doswell CA III, Brooks HE and Maddox RA. 1996. Flash flood forecasting: An ingredients-based methodology. Weather and Forecasting 11: 560-580. DOI: http://dx.doi.org/10.1175/15200434(1996)011\%3C0560:FFFAIB\%3E2.0.CO;2

Dupilka ML and Reuter GW. 2006a. Forecasting tornadic thunderstorm potential in Alberta using environmental sounding data. Part I: Wind shear and buoyancy. Weather and Forecasting 21: 325-335. DOI: http://dx.doi.org/10.1175/WAF921.1

Dupilka ML and Reuter GW. 2006b. Forecasting tornadic thunderstorm potential in Alberta using environmental sounding data. Part II: Helicity, precipitable water, and storm convergence. Weather and Forecasting 21: 336-346. DOI: http://dx.doi.org/10.1175/WAF922.1.

Durre I, Vose RS and Wuertz DB. 2006. Overview of the Integrated Global Radiosonde Archive. Journal of Climate 19: 53-68. DOI: http://dx.doi.org/10.1175/JCLI3594.1

Dyson LL. 2009. Heavy daily-rainfall characteristics over the Gauteng Province. Water SA 35: 627-638. DOI: http://dx.doi.org/10.4314/wsa.v35i5.49188

Dyson LL. 2013. Atmospheric thermodynamics and circulation associated with heavy rainfall over the Gauteng Province, South Africa. Unpublished PhD Thesis, University of Pretoria, 162.

Dyson LL and Van Heerden J. 2001. The heavy rainfall and floods over the northeastern interior of South Africa during February 2000. South African Journal of Science 97: 80-86.

Dyson LL and Van Heerden J. 2002. A model for the identification of tropical weather systems. Water SA 28: 249-258. DOI: http://dx.doi.org/10.4314/wsa.v28i3.4892. 
Dyson LL, Engelbrecht CJ, Turner KE and Landman S. 2012. A short term heavy rainfall forecasting system for South Africa with first implementation over the Gauteng Province. South African Water Research Commission Report No. 1906/1/12, 124.

Gijben M. 2012. The lightning climatology of South Africa. South African Journal of Science 108 (3/4) Art. \#740, 10. DOI: 10.4102/sajs.v108i3/4.740.

Groenemeijer PH and Van Delden A. 2007. Sounding-derived parameters associated with large hail and tornadoes in the Netherlands. Atmospheric Research 83: 473-487. DOI: http://dx.doi.org/10.1016/j.atmosres.2005.08.006

Harnack RP, Jensen DT and Cermak III JR. 1998. Investigation of upper-air conditions occurring with heavy summer rain in Utah. International Journal of Climatology 8: 701-732. http://dx.doi.org/10.1175/1520-0434(1997)012\%3C0282:IOUACO\%3E2.0.CO;2.

Hart NCG, Reason CJC and Fauchereau N. 2010. Tropical-Extratropical Interactions over Southern Africa: Three Cases of Heavy Summer Season Rainfall. Monthly Weather Review 138: 2608-2623. DOI: http://dx.doi.org/10.1175/2010MWR3070.1

Henry NL. 2000. A static stability index for low-topped convection. Weather and Forecasting 15: 246254. DOI: http://dx.doi.org/10.1175/1520-0434(2000)015\%3C0246:ASSIFL\%3E2.0.CO;2.

Holton JR. 1992. An Introducion to Dynamic Meteorology. Academic Press, 511.

Houston AL and Wilhelmson RB. 2012: The impact of airmass boundaries on the propagation of deep convection: A modeling-based study in a high-CAPE, low-shear environment. Monthly Weather Review 140. 167-183. DOI: http://dx.doi.org/10.1175/MWR-D-10-05033.1

Kalnay E and coauthors. 1996. The NCEP/NCAR 40-year reanalysis project, Bulletin of the American Meteorological Society 77: 437-470. DOI: http://dx.doi.org/10.1175/1520-0477(1996)077<0437: TNYRP>2.0.CO;2

Kruger AC. 2004. Climate of South Africa. Climate Regions. South African Weather Service WS45, 19.

Malherbe J, Engelbrecht FA, Landman WA and Engelbrecht CJ. 2012. Tropical systems from the southwest Indian Ocean making landfall over the Limpopo River Basin, southern Africa: a historical perspective. International Journal of Climatology 32: 1018-1032. DOI: 10.1002/joc.2320

Manzato A. 2003. A climatology of instability indices derived from Friuli Venezia Giulia soundings, using three different methods. Atmospheric Research 67-68: 417-454. DOI: http://dx.doi.org/10.1016/S0169-8095(03)00058-9.

Market PSA, Scofield R, KuligowskI R and Gruber A. 2003. Precipitation efficiency of warm-season Midwestern mesoscale convective systems. Weather and Forecasting 18: 1273-1285. DOI: http://dx.doi.org/10.1175/1520-0434(2003)018<1273:PEOWMM>2.0.CO;2

Omotosho JB, Balogun AA and Ogunjobi JK. 2000. Predicting monthly and seasonal rainfall, onset and cessation of the rainy season in West Africa using only surface data. International Journal of Climatology 20: 865-880. DOI: 10.1002/1097-0088(20000630)20:8<865::AID-JOC505>3.0.CO;2-R

Potvin CK, Kimberly LE and Weiss SJ. 2010. Assessing the impacts of proximity sounding criteria on the climatology of significant tornado environments. Weather and Forecasting 25: 921-930. DOI: http://dx.doi.org/10.1175/2010WAF2222368.1

Ramaswamy C. 1956. On the sub-tropical jet stream and its role in the development of large-scale convection. Tellus 8: 52. DOI: 10.1111/j.2153-3490.1956.tb01194.x 
Rasmussen EN and Blanchard DO. 1998. A baseline climatology of sounding-derived supercell and tornado forecast parameters. Weather and Forecasting 13: 1148-1164. DOI: http://dx.doi.org/10.1175/1520-0434(1998)013<1148:ABCOSD>2.0.CO;2

Reid GC and Gage KS. 1981: On the annual variation in height of the tropical tropopause. Journal of Atmospheric Science 38: 1928-1938. DOI: http://dx.doi.org/10.1175/1520-0469(1981)038<1928: OTAVIH>2.0.CO;2

Rouault M, Roy SS and Balling RC. 2013. The diurnal cycle of rainfall in South Africa in the austral summer. International Journal of Climatology 33: 770-777. DOI: 10.1002/joc.3451

Schultz DM, Schumacher PN and Doswell CA III. 2000. The intricacies of instabilites. Monthly Weather Review 128. 4143-4148. DOI: http://dx.doi.org/10.1175/1520-0493(2000)129<4143:TIOI>2.0.CO;2

Schumacher RS and Johnson RH. 2008. Mesoscale processes contributing to extreme rainfall in a midlatitude warm-season flash flood. Montly Weather Review 136: 3964-3986. DOI: http://dx.doi.org/10.1175/2008MWR2471.1

Singleton AT, and Reason CJC. 2007. A Numerical Model Study of an Intense Cutoff Low Pressure system over South Africa. Monthly Weather Review 135: 1128-1150. DOI: http://dx.doi.org/10.1175/MWR3311.1

South African Weather Bureau (SAWB). 1991. History of notable weather events in South Africa 15001990. Caelum 125. South African Weather Bureau.

Statistics South Africa (StatsSA). 2013. Regional Economic growth. [Online]. Available: http://www.statssa.gov.za/articles/16\%20Regional\%20estimates.pdf (accessed 16 October 2103).

Taljaard JJ. 1985. Cut-off lows in the South African region. South Africa. South African Weather Bureau. Technical Note No 14. 153

Taljaard JJ. 1994. Atmospheric circulation systems, synoptic climatology and weather phenomena of South Africa. Part 1 Controls of the weather and climate of South Africa. South African Weather Bureau Technical Paper No 27, 45.

Taljaard JJ. 1996a. Atmospheric circulation systems, Synoptic climatology and weather Phenomena of South Africa. Part 5 Temperature phenomena in South Africa. South African Weather Bureau Technical Paper No. 32, 53.

Taljaard JJ. 1996b. Atmospheric circulation systems, Synoptic climatology and weather Phenomena of South Africa. Part 6 Rainfall in South Africa. South African Weather Bureau Technical Paper No. $32,89$.

Todd MP. 2010. Personal communication. Chief forecaster, National Forecast Centre, South African Weather Service, Bolepi House, Pretoria.

Tyagi B, Naresh Krishna V and Satyanarayana ANV. 2011. Skill of thermodynamic indices for forecasting pre-monsoon thunderstorms over Kolkata during STORM pilot phase 2006-2008. Natural Hazards 56: 681-698. DOI:10.1007/s11069-010-9582-x

Williams E and Renno N. 1993. An analysis of the conditional instability of the tropical atmosphere. Monthly Weather Review 121: 21-36. DOI: http://dx.doi.org/10.1175/15200493(1993)121<0021:AAOTCI>2.0.CO;2 